\title{
PENGARUH PROBLEM BASED LEARNING (PBL) TERHADAP MOTIVASI DAN HASIL BELAJAR IPS SISWA KELAS VIII SMP NEGERI 13 MATARAM
}

\author{
Pendidikan Geografi Universitas Muhammadiyah Mataram, arif@yahoo.com
}

\section{INFO ARTIKEL}

RiwayatArtikel:

Diterima: 03-05-2017

Disetujui: 30-06-2017

\section{Kata Kunci: \\ 1. Problem Based Learning, \\ 2. Motivasi, \\ 3. Hasil Belajar}

\begin{abstract}
ABSTRAK
Abstrak:

Tujuan penelitian ini adalah: (1) mengetahui pengaruh Problem Based Learning (PBL) terhadap motivasi belajar siswa kelas VIII di SMP Negeri 13 Mataram dan (2) mengetahui pengaruh Problem Based Learning (PBL) terhadap hasil belajar siswa kelas VIII di SMP Negeri 13 Mataram. Penelitian ini menggunakan rancangan penelitian eksperimen semu (quasi experiment) dengan menggunakan desain penelitian pre-test and post-test group. Hasil penelitian menunjukkan bahwa tidak ada pengaruh PBL terhadap motivasi belajar siswa kelas VIII SMP Negeri 13 Mataram. Pengaruh PBL terhadap hasil belajar siswa kelas VIII di SMP Negeri 13 Mataram pada masing-masing ranah adalah: (1) ada pengaruh PBL terhadap hasil belajar sikap sosial siswa, (2) tidak ada pengaruh PBL terhadap hasil belajar spiritual siswa, (3) ada pengaruh PBL terhadap hasil belajar pengetahuan siswa (4) ada pengaruh PBL terhadap hasil belajar keterampilan siswa. Penerapan PBL untuk meningkatkan motivasi agar menjadi lebih maksimal sebaiknya dilakukan modifikasi.

The purpose of this research are: (1) to know the influence of problem-based learning $(P B L)$ to the motivation of study of class VIII students in SMP Negeri 13 Mataram and (2) to know the effect of problem-based learning (PBL) to the result of learning of class VIII students at SMP Negeri 13 Mataram. This research uses a quasi-experimental research design (quasi experiment) using pre-test and post-test group design. The result of the research shows that there is no influence of PBL on the motivation of the students of class VIII SMP Negeri 13 Mataram. The influence of PBL on the learning outcomes of grade VIII students at SMP Negeri 13 Mataram in each of the domains is: (1) there is influence of PBL on the learning result of social attitude of students, (2) no influence of PBL on student's spiritual learning result, (3) The influence of PBL on the learning outcomes of students (4) there is the influence of PBL on learning outcomes of students. Implementation of PBL to increase motivation to be more leverage.
\end{abstract}




\section{A. LATAR BELAKANG}

Pembelajaran yang baik akan mampu menghasilkan kualitas siswa yang baik. Pembelajaran yang baik adalah pembelajaran yang berpusat pada siswa (student centered) sehingga siswa akan memiliki pengalaman langsung dalam belajar. Keberhasilan dalam pembelajaran dapat dilihat dari pencapaian hasil belajar siswa. Hasil belajar merupakan tingkat kemanusiaan yang dimiliki siswa dalam menerima, menolak, dan menilai informasi yang diperoleh dalam proses belajar mengajar (Hamdu dan Agustina, 2011). Ambarsari dkk. (2013) menyatakan bahwa hasil belajar bukan hanya berupa penguasaan pengetahuan, tetapi juga kecakapan dan keterampilan dalam melihat, menganalisis, dan memecahkan masalah, membuat rencana dan mengadakan pembagian kerja sehingga baik kegiatan maupun produk yang dihasilkan dari ativitas belajar ini mendapatkan penilaian. Dengan demikian dapat disimpulkan bahwa hasil belajar yang diharapkan dalam pembelajaran harus meliputi ranah sikap, pengetahuan, dan keterampilan.

Keberhasilan siswa dalam belajar dapat dipengaruhi oleh faktor internal maupun eksternal. Menurut Hamid (2013), salah satu faktor internal yang mempengaruhi hasil belajar siswa adalah motivasi belajar. Motivasi belajar merupakan dorongan atau keinginan yang kuat untuk mencapai kepuasan di dalam individu untuk belajar, mendapatkan perubahan sehingga memenuhi kebutuhan ke arah yang lebih baik (Made dkk., 2013). Motivasi belajar menurut Keller meliputi empat ranah, yaitu attention, relevance, confidence, dan satisfaction (Riantani dan Wiludjeng, 2008). Perhatian (attention) merupakan sikap dari seseorang yang umumnya didorong oleh rasa keingintahuan. Relevansi (relevance) menunjukkan adanya hubungan materi pembelajaran dengan kebutuhan maupun kondisi siswa. Percaya diri (confidence) berupa kemampuan siswa untuk dapat berinteraksi dengan lingkungan sehingga harapan untuk berhasil pun meningkat. Keberhasilan (satisfaction) dalam mencapai suatu tujuan memberikan kepuasan bagi diri sendiri sehingga selanjutnya siswa akan berupaya mencapai tujuan yang lain dengan keberhasilan pula. Motivasi belajar siswa erat kaitannya dengan proses pelaksanaan pembelajaran dalam kelas sehingga pemilihan model pembelajaran juga harus diperhatikan oleh guru.

Hasil observasi di SMP Negeri 13 Mataram yang dilaksanakan pada hari Kamis tanggal 5 Januari 2016 di kelas VIII dengan mengambil sampel di dua kelas, yaitu kelas VIII A dan VIII B menunjukkan bahwa pihak sekolah telah menggunakan Kurikulum 2013 pada kelas VIII. Namun model pembelajaran yang digunakan guru masih belum sesuai dengan Kurikulum 2013, melainkan masih menggunakan metode tanya jawab (brain strorming).
Pelaksanaan brain strorming terbukti belum dapat memotivasi seluruh siswa untuk belajar. Motivasi belajar yang rendah ini jika dilihat dari ranah attention, maka hanya beberapa siswa yang aktif dalam pembelajaran, sementara siswa yang lain cenderung diam, tidak memperhatikan, atau berbicara sendiri. Motivasi belajar yang rendah dari ranah relevance, yaitu saat diwawancarai masih terdapat siswa yang merasa belum menemukan keterkaitan pembelajaran IPS dengan kehidupan mereka sehingga mereka belum bisa mengikuti pembelajaran dengan fokus. Motivasi belajar yang rendah dari ranah convidence, yaitu hanya beberapa siswa yang berani bertanya atau menjawab pertanyaan dari guru. Motivasi belajar yang rendah dari ranah satisfaction, yaitu berdasarkan hasil wawancara siswa merasa biasa saja saat diajar pelajaran IPS. Observasi di SMP Negeri 13 Mataram juga dilakukan pada hasil belajar siswa. Hasil belajar di kelas VIII A dan VIII B menunjukkan bahwa nilai siswa yang di bawah KKM yaitu 66,75 di kelas VIII A adalah 36\% sementara di kelas VIII B adalah 28\%.

Solusi yang ditawarkan untuk mengatasi permasalahan yang terjadi tersebut adalah menggunakan Problem Based Learning (PBL) sebagai model pembelajaran dengan menerapkan variasi metode pembelajaran yaitu ceramah, diskusi, dan praktikum. PBL adalah model pembelajaran yang menggunakan permasalahan nyata yang ditemui di lingkungan sebagai dasar untuk memperoleh pengetahuan dan konsep melalui kemampuan berpikir kritis dan memecahkan masalah (Fakhriyah, 2014). Pemilihan PBL sebagai solusi untuk meningkatkan motivasi dan hasil belajar karena melalui PBL siswa disajikan pada permasalahan dalam kehidupan sehari-hari untuk diajak terlibat aktif mencari solusinya sehingga harapannya motivasi dan hasil belajar siswa meningkat. Kelebihan lain dari mengkaitkan permasalahan dalam kehidupan sehari-hari dengan materi yang sedang dikaji adalah dapat membuat siswa lebih tahu tentang aplikasi IPS dalam memecahkan permasalahan yang ada.

Tujuan penelitian ini adalah: (1) mengetahui pengaruh Problem Based Learning (PBL) terhadap motivasi belajar siswa kelas VIII SMP Negeri 13 Mataram dan (2) mengetahui pengaruh Problem Based Learning (PBL) terhadap hasil belajar siswa kelas VIII SMP Negeri 13 Mataram. 
Tabel 3 Hasil Uji Keterlaksanaan Sintaks Pembelajaran Kelas Eksperimen

\begin{tabular}{llccccc}
\hline Model & & Sum of Squares & df & Mean Square & F & Sig. \\
\hline 1 & Regression & 433.745 & 1 & 433.745 & 4.686 & $.041^{\text {a }}$ \\
& Residual & 2129.015 & 23 & 92.566 & & \\
& Total & 2562.760 & 24 & & & \\
\hline
\end{tabular}

\section{Hasil Uji Motivasi Siswa}

Nilai signifikansi uji regresi berdasarkan Tabel 3pada kelas eksperimen adalah 0,041. Nilai signifikansi yang $<0,05$, menunjukkan bahwa sintaks $P B L$ telah dilaksanakan secara konsisten. Hasil analisis konsistensi keterlaksanaan sintaks tersebut menunjukkan bahwa treatment yang dilakukan pada kelas eksperimen dapat dikatakan terlaksana dengan baik dan konsisten.
Data motivasi belajar siswa diambil dengan menggunakan dua instrumen, yaitu melalui angket motivasi belajar yang diberikan di awal dan di akhir pertemuan dan melalui lembar observasi selama pembelajaran. Ringkasan hasil analisis data motivasi dapat dilihat pada Tabel 4 dan Tabel 5 .

Tabel 4 Ringkasan Hasil Analisis Data Motivasi Belajar

\begin{tabular}{llccl}
\hline No. & Data yang diuji & Uji Analisis & $\begin{array}{l}\text { Nilai } \\
\text { signifikansi }\end{array}$ & Keterangan \\
\hline 1. & $\begin{array}{l}\text { Angket Motivasi } \\
\text { Belajar }\end{array}$ & Uji Anakova & 0.486 & $\begin{array}{l}\text { PBL tidak berpengaruh } \\
\text { terhadap motivasi belajar } \\
\text { 2. }\end{array}$ \\
Hasil observasi & $\begin{array}{l}\text { Independent } \\
\text { sample t-test }\end{array}$ & 0.934 & $\begin{array}{l}\text { PBL tidak berpengaruh } \\
\text { terhadap motivasi belajar }\end{array}$ \\
\hline
\end{tabular}

Tabel 5 Rerata Terkoreksi Motivasi Belajar

\begin{tabular}{lccccc}
\hline Kelas & Rerata & Penyimpangan & Koreksi & Y & Rerata Terkoreksi \\
\hline Kontrol & 0.808 & 0.0188 & 0.018790047 & 20.3 & 0.793209953 \\
Eksperimen & 0.812 & 0.0206 & 0.020589094 & 19.27 & 0.750210906 \\
\hline
\end{tabular}

Nilai rerata terkoreksi motivasi belajar berdasarkan Tabel 5 pada kelas eksperimen adalah 0,75 sementara pada kelas kontrol lebih tinggi yaitu 0,79 , menunjukkan bahwa tingkat motivasi belajar kelas eksperimen 0,043 di bawah kelas kontrol.

\section{Hasil Belajar Siswa}

Hasil belajar siswa meliputi tiga ranah, yaitu sikap (spiritual dan sosial), pengetahuan, dan keterampilan. Ringkasan hasil analisis data dari masing-masing ranah hasil belajar dapat dilihat pada Tabel 6 .

Tabel 6 Ringkasan Hasil Analisis Data Hasil Belajar Siswa

\begin{tabular}{|c|c|c|c|c|}
\hline No. & Data yang diuji & Uji Analisis & $\begin{array}{l}\text { Nilai } \\
\text { signifikansi }\end{array}$ & Keterangan \\
\hline 1. & $\begin{array}{l}\text { Hasil belajar } \\
\text { sikap sosial }\end{array}$ & $\begin{array}{l}\text { Indpendent } \\
\text { sample t-test }\end{array}$ & 0.038 & $\begin{array}{l}\text { PBL berpengaruh terhadap } \\
\text { hasil belajar sikap sosial }\end{array}$ \\
\hline 2. & $\begin{array}{l}\text { Hasil belajar } \\
\text { sikap spiritual }\end{array}$ & $\begin{array}{l}\text { Independent } \\
\text { sample t-test }\end{array}$ & 0.429 & $\begin{array}{l}\text { PBL tidak berpengaruh } \\
\text { terhadap hasil belajar sikap } \\
\text { spiritual }\end{array}$ \\
\hline 3. & $\begin{array}{l}\text { Hasil Belajar } \\
\text { Pengetahuan }\end{array}$ & Uji Anakova & 0.005 & $\begin{array}{l}\text { PBL berpengaruh terhadap } \\
\text { hasil belajar pengetahuan }\end{array}$ \\
\hline 4. & $\begin{array}{l}\text { Hasil belajar } \\
\text { keterampilan }\end{array}$ & $\begin{array}{l}\text { Independent } \\
\text { sample t-test }\end{array}$ & 0.025 & $\begin{array}{l}\text { PBL berpengaruh terhadap } \\
\text { hasil belajar keterampilan }\end{array}$ \\
\hline
\end{tabular}

Nilai rerata terkoreksi untuk hasil belajar pengetahuan dapat dilihat pada Tabel 7.

Tabel 7 Rerata Terkoreksi Hasil Belajar Pengetahuan 
Arif, Pengaruh PBL

\begin{tabular}{lcrccr}
\hline Kelas & Rerata & Penyimpangan & Koreksi & Y & Rerata Terkoreksi \\
\hline Kontrol & 44.94 & -0.58 & -0.902997664 & 1701.5 & 68.96299766 \\
Eksperimen & 68.06 & -4.04 & -6.289845801 & 1903.5 & 82.4298458 \\
\hline
\end{tabular}


Nilai rerata terkoreksi pada kelas eksperimen berdasarkan Tabel 7 adalah 82,42 sementara pada kelas kontrol lebih rendah yaitu 68,96, menunjukkan bahwapencapaian hasil belajar pengetahuan siswa kelas eksperimen 13,42 lebih tinggi dari kelas kontrol

\section{B. HASIL DAN PEMBAHASAN}

1. Pengaruh model problem based learning terhadap motivasi siswa kelas VIII SMP Kelas VIII SMP Negeri 13 Mataram

Berdasarkan hasil analisa data pengaruh model pembelajaran PBL terhadap motivasi belajar siswa menggunakan uji anakova dan independent sample $t$ test didapatkan nilai signifikasi 0,486 dan 0,934 $>0,05$ sehingga $\mathrm{H}_{0}$ ditolak dan $\mathrm{H}_{\mathrm{A}}$ diterima. Hasil tersebut menunjukkan bahwa model pembelajaran PBL tidak berpengaruh terhadap motivasi belajar siswa. Hasil analisis nilai terkoreksi menunjukkan nilai kelas kontrol lebih tinggi daripada nilai kelas eksperimen, yaitu dengan selisih 0,043 sehingga dapat dikatakan penggunaan PBL tidak bisa meningkatkan motivasi siswa secara signifikan dibandingkan penerapan pendekatan ilmiah secara umum.

Hasil penelitian Sumarji (2009) menunjukkan bahwa PBL dapat meningkatkan motivasi dan kemampuan dalam memecahkan masalah dalam Statistika dari siklus pertama ke siklus kedua. Penelitian yang pernah dilakukan sebelumnya ini dapat meningkatkan motivasi belajar siswa karena penggunakan PBL sebagai treatment dibandingkan dengan penggunakan model konvensional dalam pembelajaran sebelumnya. Sementara penelitian yang baru dilakukan ini, kelas eksperimen menggunakan PBL dan kelas kontrol menggunakan pendekatan ilmiah secara umum yang telah diketahui keduanya mampu meningkatkan motivasi belajar siswa. Hasil dari peningkatan motivasi dari keduanya tidak berbeda signifikan karena prinsip antara PBL dan pendekatan ilmiah adalah sama, yaitu untuk mendapatkan pengetahuan dengan prosedur yang didasarkan pada suatu metode ilmiah (Atsnan dan Ghazali, 2013). Jadi dapat dikatakan tidak ada pengaruh PBL terhadap motivasi belajar siswa kelas VIII SMP Negeri 13 Mataram sehingga perlu adanya variasi dalam penerapan PBL. Variasi yang dapat dilakukan dalam penerapan PBL adalah dengan memadukan PBL dengan model pembelajaran yang lain, misalnya model cooperative learning karena keduanya terdapat kesamaan dalam praktik pembelajarannya, yaitu siswa belajar dalam bentuk kelompok.

\section{Pengaruh Problem Based Learning (PBL) terhadap Hasil Belajar Sikap Sosial Siswa Kelas VIII SMP Negeri 13 Mataram}

Berdasarkan hasil uji statistik menggunakan independent sample t-test diperoleh nilai signifikasi $0,038<0,050$ sehingga $H_{0}$ ditolak dan $H_{A}$ diterima. Hal tersebut menunjukkan bahwa model pembelajaran PBL berpengaruh terhadap hasil belajar sikap sosial siswa. Rachmawati (2011) menyatakan bahwa penerapan PBL dapat meningkatkan keaktifan siswa dalam belajar di kelas V SDN Pringapus 2 Trenggalek. Widodo (2013) menyatakan PBL dapat meningkatkan aktivitas belajar siswa kelas VIIA di MTs Donomulyo, Nanggulan, Kulon Progo pada pokok bahasan wujud zat dan perubahannya.

Aspek sosial yang diukur dalam penerapan PBL ini adalah keaktifan dan kerjasama. Berdasarkan hasil pengamatan selama proses pembelajaran keaktifan siswa terlihat dari proses diskusi para siswa dalam kelompok kecil untuk memecahkan permasalahan yang disajikan. Siswa juga aktif dalam memberikan respon balik dari pendapat teman maupun dalam menjawab pertanyaan yang diberikan guru. Kerjasama antar siswa juga terlihat dari cara pembagian tugas masing-masing anggota kelompok dalam melakukan kegiatan praktikum atau pun dalam menyelesaikan LKS. Proses pembelajaran yang aktif ini dapat berjalan dengan baik, karena penggunaan model pembelajaran PBL menuntut siswa untuk terlibat aktif dalam pembelajaran. Lasmawan (2010) menyatakan salah satu kelebihan PBL adalah dapat meningkatkan aktivitas siswa dalam kegiatan pembelajaran.

Adanya pengaruh PBL terhadap hasil belajar sikap sosial ini tidak terlepas dari karekteristik PBL yang menggunakan "masalah" untuk menstimulasi, mengkontekstualkan, dan mengintegrasikan pembelajaran (Newman, 2005). Tuntutan bagi siswa dari karakteristik PBL inilah yang menjadikan mereka harus berinteraksi dan bekerjasama dengan teman yang lain dalam memecahkan permasalahan yang disajikan. Alasan lain PBL dapat meningkatkan hasil belajar sikap sosial terkait dengan sintaks dari PBL, khususnya pada tahap mengorganisasikan siswa untuk belajar, membantu penyelidikan siswa, dan mengembangkan dan menyajikan hasil karya.

\section{Pengaruh Problem Based Learning (PBL) terhadap Hasil Belajar Sikap Spiritual Siswa Kelas VIII SMP BNegeri 13 Mataram}

Berdasarkan hasil uji statistik menggunakan independent sample t-test diperoleh nilai signifikasi 0,429>0,050 sehingga $H_{0}$ diterima dan $H_{A}$ ditolak. Hal tersebut menunjukkan bahwa model pembelajaran PBL tidak berpengaruh terhadap hasil belajar sikap spiritual siswa. Ketidakberpengaruhan PBL terhadap hasil belajar sikap spiritual kelas eksperimen bukan karena hasil spiritual dari kelas eksperimen rendah, tetapi karena hasil 
belajar sikap spiritual antara kelas eksperimen dan kelas kontrol yang menggunakan pendekatan ilmiah secara umum sama-sama tinggi. Hal ini terjadi karena pada prakteknya baik di kelas eksperimen maupun kelas kontrol sama-sama terdapat penyampaian pesan yang dapat dipetik atau nasehat di setiap akhir pembelajaran. Selain itu, guru juga selalu mengajak siswa untuk merefleksikan materi pembelajaran yang sedang dipelajari dengan pola hidup sehari-hari, sehingga siswa terbiasa bersyukur dan menjaga diri. Perlakuan yang sama tentang penyampaian nasehat di akhir pembelajaran dan reflesksi diri sudah merupakan anjuran dari Kurikulum 2013 yang merupakan pokok dari PBL maupun pendekatan ilmiah sendiri. Hartono dkk. (2015) menyatakan pendekatan ilmiah sebagai pendukung Kurikulum 2013 diyakini dapat mengembangkan sikap, keterampilan, dan pengetahuan siswa. Oleh karenanya dapat dikatakan prinsip dari PBL dan pendekatan ilmiah pada dasarnya adalah sama, yaitu ingin menciptakan siswa yang baik dalam hasil belajar pengetahuan maupun sikap dan keterampilan.

4. Pengaruh Problem Based Learning (PBL) terhadap Hasil Belajar Pengetahuan Siswa Kelas VIII SMP Negeri 13 Mataram

Berdasarkan hasil uji statistik menggunakan uji anakova diperoleh nilai signifikasi $0,005<0,050$ sehingga $\mathrm{H}_{0}$ ditolak dan $\mathrm{H}_{\mathrm{A}}$ diterima. Hal tersebut menunjukkan bahwa model pembelajaran PBL berpengaruh terhadap hasil belajar pengetahuan siswa. Analisis nilai terkoreksi menunjukkan nilai kelas eksperimen lebih tinggi daripada nilai kelas kontrol, yaitu dengan selisih 13,42 yang berarti model pembelajaran PBL berdampak positif terhadap motivasi belajar siswa atau dengan kata lain penggunaan PBL dapat meningkatkan hasil belajar siswa secara signifikan daripada penerapan pendekatan ilmiah secara umum. Surjono dan Wulandari (2013) menyatakan terdapat perbedaan hasil belajar yang signifikan antara siswa yang diajar dengan metode PBL dengan siswa yang diajar dengan metode pembelajaran demonstrasi. Hasanah (2012) juga menyatakan bahwa siswa yang diajar dengan menggunakan model PBL memperoleh rata-rata hasil belajar pengetahuan lebih tinggi dibanding rata-rata hasil belajar yang menggunakan pembelajaran konvensional. Fadlillah (2014) menyatakan bahwa penerapan pembelajaran menggunakan PBL dapat meningkatkan hasil belajar siswa SMP Muhamadiyah 1 Malang pada pokok bahasan materi transformasi.

Pencapaian hasil belajar dengan menggunakan PBL dapat lebih maksimal karena PBL merupakan teknik yang cukup baik dalam memahami isi pelajaran, dapat menantang kemampuan siswa serta memberikan kepuasan untuk menemukan pengetahuan baru bagi siswa, dapat membantu siswa untuk mentransfer pengetahuan untuk memahami masalah dalam kehidupan nyata, dan dapat membantu siswa mengembangkan pengetahuan barunya (Lasmawan, 2010). Faktor lain penerapan PBL dapat meningkatkan hasil belajar pengetahuan adalah terkait sintaks dari PBL sendiri, khususnya pada tahap membantu penyelidikan siswa dan mengembangkan dan menyajikan hasil karya siswa. Kelebihan penerapan PBL yang lain adalah membantu siswa untuk mencapai tingkatan berpikir C1 sampai C6, karena PBL menggunakan permasalahan nyata yang ditemui di lingkungan sebagai dasar untuk memperoleh pengetahuan dan konsep sehingga dapat melatih siswa untuk berpikir kritis dan memecahkan masalah (Fakhriyah, 2014).

\section{Pengaruh Problem Based Learning (PBL) terhadap Hasil Belajar Ketrampilan Siswa Kelas VIII SMP Negeri 13 Mataram}

Berdasarkan hasil uji statistik menggunakan independent sample t-test diperoleh nilai signifikasi $0,025<0,050$ sehingga $\mathrm{H}_{0}$ ditolak dan $\mathrm{H}_{\mathrm{A}}$ diterima. Hal tersebut menunjukkan bahwa model pembelajaran PBL berpengaruh terhadap hasil belajar keterampilan siswa. Hal ini sesuai dengan harapan dari proses pembelajaran PBL yang siswa tidak diharapkan hanya sekadar mendengarkan, mencatat kemudian menghafal materi pelajaran, akan tetapi dengan PBL siswa aktif berpikir, berkomunikasi, mencari dan mengolah data, serta akhirnya menyimpulkan (Dewi dkk., 2024). Harapan penerapan PBL ini semisi dengan hasil belajar keterampilan yang dimaksudkan di sini, yaitu meliputi kemampuan untuk mengamati, menanya, mencoba atau mengumpulkan informasi, menalar, dan mengkomunikasikan atau lebih dikenal dengan istilah 5M.

Hasil belajar pengetahuan dan keterampilan siswa diperoleh dari usaha mengkonstruksi sendiri pengetahuanya dengan keterampilan baru (Sumarji, 2009). Cara mengkonstruksikan pengetahuan sendiri dengan keterampilan baru berkaitan dengan sintaks PBL sendiri. Sintaks PBL menurut Made dkk. (2013) meliputi lima tahap yaitu orientasi siswa pada masalah, mengorganisasikan siswa untuk belajar, membantu penyelidikan siswa, mengembangkan dan menyajikan hasil karya, serta menganalisis dan mengevaluasi proses pemecahan masalah.

\section{SIMPULAN DAN SARAN}

Berdasarkan penelitian yang telah dilakukan, maka dapat diambil kesimpulan sebagai berikut.

1. Tidak ada pengaruh Problem Based Learning (PBL) terhadap motivasi belajar siswa kelas VIII di SMP Negeri 13 Mataram dan selisih nilai rerata terkoreksi kelas eksperimen 0,043 di bawah kelas kontrol.

2. Pengaruh Problem Based Learning (PBL) terhadap hasil belajar siswa kelas VIII di SMP Negeri 13 
Mataram yaitu: (1) Ada pengaruh Problem Based Learning (PBL) terhadap hasil belajar sikap sosial siswa, (2) Tidak ada pengaruh Problem Based Learning (PBL) terhadap hasil belajar spiritual siswa, (3) Ada pengaruh Problem Based Learning (PBL) terhadap hasil belajar pengetahuan siswa dengan selisih nilai terkoreksi kelas eksperimen 13,47 lebih tinggi dari kelas kontrol, dan (4) Ada pengaruh Problem Based Learning (PBL) terhadap hasil belajar sikap keterampilan.

Berdasarkan kesimpulan tersebut sebaiknya dilakukan modifikasi PBL misalnya dipadu dengan model cooperative learning atau juga bisa dipadu dengan pembuatan cergam atau mind mapping dengan harapan agar lebih mampu meningkatkan motivasi belajar siswa.

\section{DAFTAR RUJUKAN}

Ambarsari, W., Santosa, S., Maridi. 2013. Penerapan Pembelajaran Inkuiri Terbimbing terhadap Keterampilan Proses Sains Dasar pada Pelajaran Biologi Siswa Kelas VIII SMP Negeri 7 Surakarta. Pendidikan Biologi. Volume 5, Nomor 1 Halaman 81-95.

(Online)

(http://eprints.uns.ac.id/14409/1/1441-3199-1SM.pdf), diakses tanggal 26 November 2014.

Atsnan, M.F. dan Ghazali, R.Y. 2013. Penerapan Pendekatan Scientific dalam Pembelajaran Matematika Smp Kelas VII Materi Bilangan (Pecahan). Makalah dipresentasikan dalam Seminar Nasional Matematika dan Pendidikan Matematika dengan tema " Penguatan Peran Matematika dan Pendidikan Matematika untuk Indonesia yang Lebih Baik" pada tanggal 9 November 2013 di Jurusan Pendidikan Matematika FMIPA UNY. (Online)

(http://eprints.uny.ac.id/10777/1/P\%20-

\%2054.pdf), diakses tanggal 10 Maret 2015.

Dewi, P.S.U., Sadia, W.I., Suma, K. 2014. Pengaruh Model Problem Based Learning terhadap Kemampuan Pemecahan Masalah Fisika melalui Pengendalian Bakat Numerik Siswa SMP. E-Journal Program Pascasarjana Universitas Pendidikan Ganesha. Volume 4. (Online) 0, diakses tanggal 2 Juli 2015.

Fadlillah, H. N. 2014. Peningkatan Hasil Belajar Matematika melalui Metode Problem Based Learning. Jurnal Penelitian Pendidikan. Volume 1, Nomor 1, Juni 2014, hlm. 33-39 (Online) (http://ejournal.umm.ac.id/index.php/jps/article /viewFile/1950/2050), diakses tanggal 3 Pebruari 2015.

Fakhriyah, F. 2014. Penerapan Problem Based Learning dalam Upaya Mengembangkan Kemampuan Berpikir Kritis Mahasiswa. Jurnal Pendidikan IPA
Indonesia, 3 (1): hlm. 95-101. (Online) (http://journal.unnes.ac.id/nju/index.php/jpii), diakses tanggal 25 Juni 2015.

Hamid, M. 2013. Hubungan antara Motivasi dengan Prestasi Belajar Ekonomi Siswa Kelas VIII SMP Negeri 2 Jangka Kabupaten Bireuen. LENTERA, 13(4): hlm. 12-21. (Online) (http://118.97.150.18/jurnal/index.php/LTR1/ar ticle/viewFile/172/106), diakses tanggal 3 Pebruari 2015.

Hasanah, N. 2012. Pengaruh Model Pembelajaran Problem Based Learning terhadap Hasil Belajar Siswa pada Pembelajaran PLH Kelas X Materi Kerusakan Tanah dan Lahan. Skripsi tidak diterbitkan. Malang: Universitas Negeri Malang. 